\title{
Dottie and the Plymouth Rocks
}

Now it's dark, and our imagining is easier. The single bulb is burning in the chicken house.

Don't touch that wire. Electricity will seize

hold of you, Dottie; the current will seize hold and melt the metal buttons off your blouse.

Now it's dark: imagining is easier.

If there's a lion in the chicken house, it's sire of our trouble then; Detroit Edison cannot roust

the beast. An agency is coming out to seize

the stove. The rooster's wild, with rapierlike spurs. Please, don't try to corner him! Use common sense; then, imagining is easier.

The hens are brooding on glass eggs: four-year hens: They're all laid out. Such ammonia would unhouse the lion's roar, but it's immune to seizures.

The lion hasn't any lungs. This bare wire lion. This bad ground lion. This meter counting up bad debts: Imagining

this dark is easy, the lion eating hens, glass, light, everything it sees. 